\title{
Gelatin Properties of Goat Skin Produced by Calcium Hydroxide as Curing Material
}

\author{
M. I. Said ${ }^{\mathrm{a}, *}$, S. Triatmojo ${ }^{\mathrm{b}}$, Y. Erwanto ${ }^{\mathrm{b}}$, \& A. Fudholi \\ ${ }^{a}$ Faculty of Animal Science, Hasanuddin University \\ Jln. Perintis Kemerdekaan Km.10, Makassar 90245 Indonesia \\ ${ }^{\mathrm{b}}$ Faculty of Animal Science, Gadjah Mada University \\ Jln. Fauna 3 Bulaksumur, Yogyakarta 55281 Indonesia \\ 'Faculty of Pharmacy, Gadjah Mada University \\ Sekip Utara, Yogyakarta 55281 Indonesia \\ (Received 14-12-2010; accepted 25-08-2011)
}

\begin{abstract}
ABSTRAK
Penerapan basa kuat sebagai bahan curing telah banyak diterapkan dalam industri gelatin komersial, namun penerapan basa lemah belum banyak dilakukan. Penerapan basa kuat sebagai bahan curing tidak ekonomis dan diduga dapat berpengaruh bagi kesehatan manusia. Penelitian dilakukan untuk mempelajari sifat-sifat gelatin kulit kambing yang diproduksi menggunakan basa lemah jenis $\mathrm{Ca}(\mathrm{OH})_{2}$ dan selanjutnya dibandingkan dengan sifat-sifat gelatin komersial. Kulit kambing dari jenis Bligon (hasil persilangan kambing etawah dan kacang) jantan umur 1,5-2,5 tahun digunakan sebagai bahan baku dan $\mathrm{Ca}(\mathrm{OH})_{2} 100 \mathrm{~g} / 1$ sebagai bahan curing. Rancangan acak lengkap pola faktorial $2 \times 3$ dengan 3 ulangan digunakan sebagai desain penelitian. Dua waktu curing ( 2 dan 4 hari) dan tiga konsentrasi bahan $(3,6,9 \% \mathrm{v} / \mathrm{v})$ digunakan sebagai perlakuan serta gelatin komersial (murni oleh Merck, standar pangan dan standar farmasi) digunakan sebagai kontrol. Gelatin yang diproduksi dari kulit kambing menggunakan $\mathrm{Ca}(\mathrm{OH})_{2}$ memiliki sifat yang mirip dengan gelatin komersial. Kadar logam berat $(\mathrm{Pb}, \mathrm{Cu}$, dan $\mathrm{Zn})$ yang dikandung dalam produk gelatin kulit kambing masih memenuhi standar yang dipersyaratkan SNI. Produksi gelatin optimum dihasilkan dari penerapan waktu curing 4 hari pada konsentrasi $9 \%(\mathrm{v} / \mathrm{v})$.
\end{abstract}

Kata kunci: kulit kambing, bahan curing, basa lemah, sifat gelatin

\begin{abstract}
Application of strong bases as curing materials has been widely applied in commercial gelatin industries, but the application of weak bases has not been much done. Application of strong bases as a treatment was not economical and assumed to affect human health. Studies were conducted on the properties of goat skin gelatin manufactured using weak base types of $\mathrm{Ca}(\mathrm{OH})_{2}$ and then compared with properties of commercial gelatin. Skins from Bligon goats of 1.5 to 2.5 years old was used as the raw materials and $\mathrm{Ca}(\mathrm{OH})_{2} 100 \mathrm{~g} / 1$ as curing materials. The $2 \times 3$ factorial completely randomized design (CRD) with three replications was used as a design study. Two curing times ( 2 and 4 days) and three concentrations $(3,6,9 \% \mathrm{v} / \mathrm{v})$ were used as treatments, and commercial gelatin (pure (P) by Merck, food grade (Fg) and pharmacy standards (Ps)) were used as control. Gelatin produced from goat skins using $\mathrm{Ca}(\mathrm{OH})_{2}$ had properties similar to that of commercial gelatin. The heavy metals $(\mathrm{Pb}, \mathrm{Cu}$ and $\mathrm{Zn})$ contained in goat skin gelatin still meet the INS standards. The optimum production of gelatin has been generated through the application of 4-day curing time at a concentration of $9 \%(\mathrm{v} / \mathrm{v})$.
\end{abstract}

Key words: goat skin, curing materials, weak base, gelatin properties

\section{INTRODUCTION}

The amount of commercial gelatin as a raw material of food and pharmaceutical industries in the country is

\footnotetext{
* Corresponding author:
}

e-mail: irfanmks@yahoo.com still very limited, so it is necessary to seek new sources of gelatin. Recently, scientists have been doing many research related to the search for alternative sources of gelatin halal (Gilsenan et al., 2000; Gómez-Guillén et al., 2002; Hidaka \& Liu, 2002; Grobben et al., 2004; Giménez et al., 2005; Chiou et al., 2008; Duan et al., 2008; GómezEstaca et al., 2008; Jongjareonrak et al., 2008). 
In the process of gelatin production required a curing step to improve the quality of gelatin (Kolodziejska et al., 2003). Curing materials from the group of acids and bases (strong or weak) have been widely applied in gelatin production process from raw materials, particularly the skin and bones of fish (Gudmundsson, 2002; Jamilah \& Harvinder, 2002; Kolodziejska et al., 2003; Kittiphattanabawon et al., 2005; Kasankala et al., 2007) and then those of cattle sheep, pigs and chickens; while the application of curing material from the skin of a goat have not been published. So far, the use of strong acid (i.e. $\mathrm{HCl}$ ) and strong base (i.e. $\mathrm{NaOH}$ ) as curing materials of commercial gelatin production process is expensive and it is assumed to affect human health.

The use of curing materials of weak base (ie. $\left.\mathrm{Ca}(\mathrm{OH})_{2}\right)$ has not been widely applied, especially in the production process of gelatin made from raw goat skins. $\mathrm{Ca}(\mathrm{OH})_{2}$ is more economical as well as relatively safe for human health and easier to obtain. The application of the curing time and the concentration of $\mathrm{Ca}(\mathrm{OH})_{2}$, with the right combination are required in the production of gelatin with properties better than the manufacturing process. The use of curing materials with incorrect combination can be affected by the quality of gelatin (Wang et al., 2008b; Zeugolis et al., 2008). In this case, the study was conducted to determine the properties of gelatin made from goat skins manufactured using materials curing $\mathrm{Ca}(\mathrm{OH})_{2}$ and to determine the optimal treatment combination.

\section{MATERIALS AND METHODS}

\section{Materials}

A total of 10 pieces of goat skin from Bligon male, 1.5 to 2.5 years old were used as a raw material. Bligon goat is a hybrid from Ettawah goat type with Kacang. Calcium hydroxide $\left(\mathrm{Ca}(\mathrm{OH})_{2} 100 \mathrm{~g} / \mathrm{l}\right)$ was used as a curing material.

\section{Procedures}

Preparation of raw materials. Raw skin was weighed and washed in running water for $30 \mathrm{~min}$. Raw skin was soaked in a solution of $1 \%$ teepol and washed in running water for $15 \mathrm{~min}$. Fleshing machine was used to remove the remaining flesh and fat. Solution of $2 \%$ lime $+3 \% \mathrm{Na}_{2} \mathrm{~S}$ was used in unhairing process. The skin was washed with running water for $15 \mathrm{~min}$ and continued with the process of neutralization in a solution of $2 \% \mathrm{HCOOH}(\mathrm{pH} 7-7-$ $5)$. Sheets of skin without hair were cut into small pieces the size of $3 \times 3 \mathrm{~cm}$. The skin pieces were combined into a single (composite) for use as raw material of gelatin.

Preparation of curing solution. Calcium hydroxide $\left(\mathrm{Ca}(\mathrm{OH})_{2} 100 \mathrm{~g} / \mathrm{l}\right)$ concentrations of $3 \%, 6 \%$, and $9 \%(\mathrm{v} / \mathrm{v})$ were used as treatments. Curing solution concentration of $3 \%, 6 \%$, and $9 \%$ was made by dissolving $\mathrm{Ca}(\mathrm{OH})_{2} 100$ $\mathrm{g} / \mathrm{l}$ each of 3, 6 and $9 \mathrm{ml}$ into a flask containing $100 \mathrm{ml}$ of distilled water to limit the volume of $100 \mathrm{ml}$.
Preparation of materials. Gelatin was produced in accordance with Ockerman \& Hansen (2000) methods. The composite raw material soaked in a curing solution at $5-10{ }^{\circ} \mathrm{C}$ temperature. The curing time and concentration of the solution was used to adapt to treatment. Raw materials were neutralized with acetic acid to $\mathrm{pH} 6$ to 7.5 , weighed and extracted. The extraction process was performed on three steps: step I (55-60 $\left.{ }^{\circ} \mathrm{C}\right)$; step II (60-65 $\left.{ }^{\circ} \mathrm{C}\right)$, and step III $\left(65-70{ }^{\circ} \mathrm{C}\right)$ each for 3 hours. The extract was filtered and concentrated at $70{ }^{\circ} \mathrm{C}$ for 2 hours. It was cooled in a refrigerator at $5-10{ }^{\circ} \mathrm{C}$ for $30 \mathrm{~min}$ and dried at $55^{\circ} \mathrm{C}$ for $18-20$ hours until the gelatin sheet solid. The gelatin sheets were milled and packaged in vacuum plastic to test its properties.

\section{Method of Analysis}

Gel strength (Muyonga et al., 2004 ; Liu et al., 2008) (Modification). Gel strength was measured with a Universal Testing Machine (Zwick/Z 0.5). Gelatin solution 6.67\% w/ $\mathrm{v}$ (6.67 grams to $100 \mathrm{ml}$ distilled water) was heated at the temperature of $\pm 60^{\circ} \mathrm{C}$ to dissolve the particles. Solution in the container $\varnothing 5 \mathrm{~cm}$ and a height of $6 \mathrm{~cm}$ was stored at $5{ }^{\circ} \mathrm{C}$ for $16-18$ hours. Gelatin was placed at the bottom of the plunger $(\varnothing=13 \mathrm{~mm})$. The test was conducted at the temperature of $\pm 10{ }^{\circ} \mathrm{C}$ and the speed $10 \mathrm{~mm} / \mathrm{min}$ as deep as $4 \mathrm{~mm}$ was used as plunger. The value of gel strength ( $\mathrm{g}$ Bloom) used the formula $=20+2.86 .10-3 \mathrm{D}$, where $\mathrm{D}=\mathrm{F} / \mathrm{G}$ x 980, $\mathrm{F}=$ height chart before fracture; $\mathrm{G}=$ constant (0.07).

Protein content (AOAC, 2005). FOSS Kjeltec 2200 was used to determine protein content. A total of $0.5 \mathrm{~g}$ of sample $+1 / 4$ bussino tablet $+12 \mathrm{ml}$ of $\mathrm{H}_{2} \mathrm{SO}_{4}$ was concentrated in the destruction of the tube FOSS at $\pm 410^{\circ} \mathrm{C}$ for 1 hour. The results of destruction was distilled with thio- $\mathrm{NaOH}$ $40 \%+\mathrm{H}_{3} \mathrm{BO}_{4} 4 \%+$ BCGMR indicators. A total of $150 \mathrm{ml}$ was destilated in erlemenyer disk and titrated with 0.099 $\mathrm{N} \mathrm{HCl}$ until the color changed from blue to pink. Five point fifty five (5.55) was used as the conversion factor of gelatin protein. The protein content (\%) was calculated using the formula $=((\mathrm{ml} \mathrm{HCl}-\mathrm{ml}$ Blanko $) \times \mathrm{N} \mathrm{HCl} \times$ $14,008 \times 100 \times 5,55) / g$ sample $\times 1000$.

Fat content (AOAC, 2005). A total of $2 \mathrm{~g}$ sample + petroleum ether was incorporated into the Soxhlet flask which was dried at $105^{\circ} \mathrm{C}$ for 2 hours. Water bath for \pm 3 hours was used to reflux process, dried in the oven for 1 hour $\pm 105{ }^{\circ} \mathrm{C}$, and cooled in a desiccator. The fat content $(\%)$ was calculated using the formula $=($ fat weight $(\mathrm{g}) / \mathrm{sample}$ weight (g)) x100\%.

Water activity $\left(\mathrm{a}_{\mathrm{w}}\right)$ (Sudarmadji et al., 2007). $\mathrm{a}_{\mathrm{w}}$ meter (Decagon Divice Pullman WA 99163, USA) was used to determine the $\mathrm{a}_{\mathrm{w}}$ value. A total of $3 \mathrm{~g}$ sample was placed at the bottom of the $\mathrm{a}_{\mathrm{w}}$ meter, left for $3 \mathrm{~min}$, and the result could be read on the monitor.

Heavy metals content (AOAC, 2005). Heavy metals content was determined by atomic absorption spectroscopy (AAS) (Perkin Elmer 3110). Samples residual ash content $+2 \mathrm{ml} \mathrm{HCl}+0.5 \mathrm{ml}$ were concentrated with $\mathrm{HNO}_{3}$ and evaporated until dry. One $\mathrm{ml}$ of $\mathrm{HCl} 1 \mathrm{~N}$ and $15 \mathrm{ml}$ 
aquadest was added to the rest and warmed for several minutes. The results were filtered and washed until 100 $\mathrm{ml}$ filtrate was obtained. A total of $8 \mathrm{ml}$ of filtrate was diluted with aquadest until the reach volume $25 \mathrm{ml}$ and the value of heavy metals was determined.

Organoleptic characteristics (Soekarto, 2008). Goat skin gelatin products and commercial were packaged with plastic clips and then photographed with a digital camera (Olympus FE-20).

\section{Experimental Design and Data Analysis}

A 2x3 completely randomized design (CRD) factor with three replications was used as the experimental design. Factor I, two curing time ( 2 and 4 days), and factor II, three concentrations of curing materials (3, 6 and $9 \% \mathrm{v} / \mathrm{v}$ ), each was repeated 3 times. Data results of an experiment (gel strength, protein content, fat content and aw value) were analyzed by ANOVA, while the data content of heavy metals and organoleptic characteristics of gelatin were analyzed descriptively. The treatment showing a significant effect was tested its difference by Duncan Multiple Range Test (DMRT) at 5\% level.

\section{RESULTS AND DISCUSSION}

\section{Gel Strength}

Gel strength of gelatin is very important on physical properties. Gel strength is affected by hydrogen bonds between water molecules and free hydroxyl groups of amino acid groups, the size of the protein chain, concentration, and molecular weight distribution of gelatin (Bhat \& Karim, 2009). The comparison between gel strength of gelatin produced from goat skin and commercial gelatin was presented in Figure 1.

The increasing use of $\mathrm{Ca}(\mathrm{OH})_{2}$ concentration tends increased the value of gel strength (Figure 1). Gel strength of goat skin gelatin produced in the range of 75.77 to $97.81 \mathrm{~g}$ Bloom is lower than that of commercial gelatin. The highest gel strength of the production process used concentration of $9 \% \mathrm{Ca}(\mathrm{OH})_{2}$ with a curing time of 4 days. Gel strength of gelatin was affected by concentration of curing materials. Application of high concentrations of curing materials in gelatin production process tends to increase the gel strength values (Ockerman \& Hansen, 2000). Gel strength was affected by the concentration of materials and curing time, it is one parameter to determine the physical quality of a product on gelatin (Kolodziejska et al., 2003). The concentration, curing times, and temperature had significant effect on the amount of collagen which dissolved during the extraction process (Wang et al., 2008 ${ }^{\mathrm{b}}$ ). The concentration is one important variable that can affect the ability to extract collagen (Zhang et al., 2007).

The application of different concentration and curing time and their interaction had significant effect $(\mathrm{P}<0.01)$ on the gel strength. Gel strength properties were associated with hydrogen bonds between water molecules and free hydroxyl groups of amino acid groups, the size of the protein chain, concentration, and molecular weight distribution of collagen (Arnesen \& Gildberg, 2002; Bhat \& Karim, 2009). In general, gel strength of gelatin was produced close to the results obtained by previous researcher that was 75-275 g Bloom (Ockerman \& Hansen, 2000).

\section{Protein Content}

Gelatin is the collagen protein, a group derived from the structural proteins and extracellular matrix and produced in large quantities (Karim \& Bhat, 2008). The difference in curing time and concentration of $\mathrm{Ca}(\mathrm{OH})_{2}$ and their interaction had no significant effect on protein content of gelatin (Table 1). This may be caused by differences in the rate applied. According to Wang et al. (2008a), the decreasing of amino acids concentrations led to some bonds that form the collagen protein to break down. Furthermore, Muyonga et al. (2003) explained that the curing material could damage the structure of the amino acids on the denaturation process.

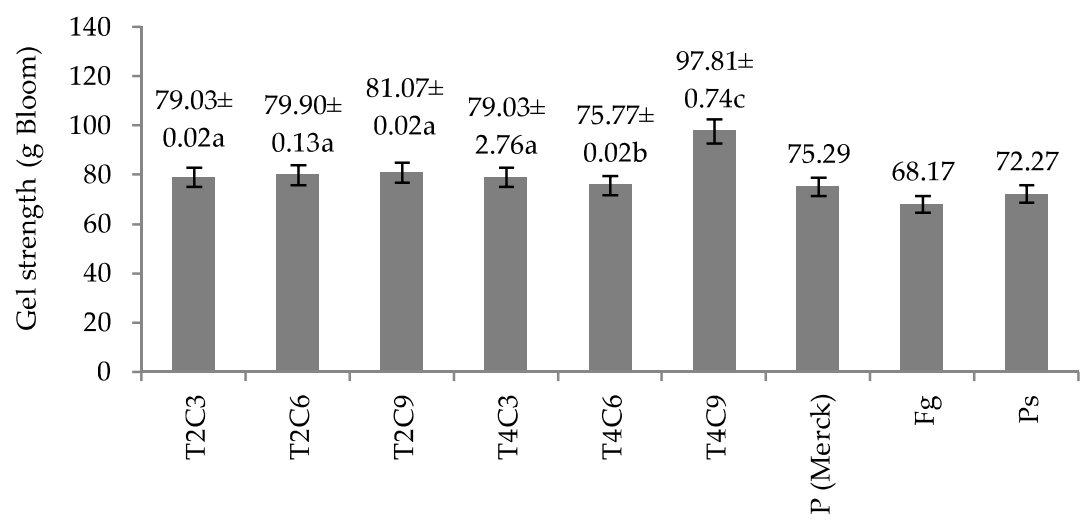

Gelatin products

Figure 1. Gel strength comparison of goat skin gelatin with commercial and INS; T2= curing time of 2 days; T4= curing time of 4 days; $\mathrm{C} 3=$ concentration of $3 \% \mathrm{Ca}(\mathrm{OH})_{2} ; \mathrm{C} 6=$ concentration of $6 \% \mathrm{Ca}(\mathrm{OH})_{2} ; \mathrm{C} 9=$ concentration of $9 \% \mathrm{Ca}(\mathrm{OH})_{2} ; \mathrm{P}=$ pure by merck; $\mathrm{Fg}=$ food grade; $\mathrm{Ps}=$ pharmacy standart; INS= Indonesian National Standards. Means with different superscript differ significantly $(\mathrm{P}<0.05)$. 
Table 1. Protein content (\%) of gelatin from goat skin in some conditions

\begin{tabular}{cccc}
\hline \multirow{2}{*}{$\begin{array}{c}\text { Curing time } \\
\text { (days) }\end{array}$} & \multicolumn{3}{c}{ Concentration of $\mathrm{Ca}(\mathrm{OH})_{2}(\%)(\mathrm{v} / \mathrm{v})$} \\
\cline { 2 - 4 } & 3 & 6 & 9 \\
\hline 2 & $92.05 \pm 0.89$ & $92.03 \pm 1.63$ & $93.60 \pm 2.37$ \\
4 & $91.63 \pm 2.53$ & $93.01 \pm 1.25$ & $92.45 \pm 2.03$ \\
\hline
\end{tabular}

Protein content from goat skin gelatin was not different from commercial gelatin (Table 4). Songchotikunpan et al. (2007) said that $89.4 \%$ protein content of gelatin was produced from Red Tilapia fish (Oreochromis niloticus) and 80.9\%-86.6\% from sword fish (Astawan \& Aviana, 2003).

\section{Fat Content}

The application of curing time and concentration of $\mathrm{Ca}(\mathrm{OH})_{2}$ and their interaction had no significant effect on the fat content (Table 2). This might be caused by the use of the same extraction temperature in the production process. In the skin, there was a great amount of fat that was bound to proteins (lipoproteins). At the time of the extraction process with the same temperature, the protein would be broken, followed by the release of fatty molecules that were bound. According to Zeugolis et al. (2008) and Wang et al. (2008b), during the extrac-

Table 2. Fat content (\%) of gelatin from goat skin in some conditions

\begin{tabular}{cccc}
\hline \multirow{2}{*}{$\begin{array}{c}\text { Curing time } \\
\text { (days) }\end{array}$} & \multicolumn{3}{c}{ Concentration of $\mathrm{Ca}(\mathrm{OH})_{2}(\%)(\mathrm{v} / \mathrm{v})$} \\
\cline { 2 - 4 } & 3 & 6 & 9 \\
\hline 2 & $0.45 \pm 0.23$ & $0.55 \pm 0.29$ & $0.43 \pm 0.19$ \\
4 & $0.45 \pm 0.19$ & $0.48 \pm 0.25$ & $0.43 \pm 0.19$ \\
\hline
\end{tabular}

tion process, it will cleavage structures of protein until it finally dissolves.

The fat content of goat skin gelatin and that of commercial gelatin did not differ much (Table 4). The previous results also showed that the fat content $0.3 \%$ from Red Tilapia fish (Oreochromis niloticus) (Songchotikunpan et al., 2007) and $0.47 \%$ to $1.7 \%$ from sword fish (Astawan \& Aviana, 2003) was same with commercial gelatin.

\section{Water Activity $\left(a_{w}\right)$ Value}

The application of curing time and concentration and their interaction had no significant effect on the $a_{w}$ value (Table 3 ). These results may be due to the same drying temperature, while $a_{w}$ value was more related to the storage time factor. According to Yudhabuntara (2008), the $a_{w}$ value was associated with microbial growth in products for the storage process. $a_{w}$ value basically had no total amount of water contained in the product, but the amount of water available was for
Table 3. Water activity $\left(a_{w}\right)$ value of gelatin from goat skin in some conditions

\begin{tabular}{cccc}
\hline \multirow{2}{*}{$\begin{array}{c}\text { Curing time } \\
\text { (days) }\end{array}$} & \multicolumn{3}{c}{ Concentration of $\mathrm{Ca}(\mathrm{OH})_{2}(\%)(\mathrm{v} / \mathrm{v})$} \\
\cline { 2 - 4 } & 3 & 6 & 9 \\
\hline 2 & $0.35 \pm 0.06$ & $0.34 \pm 0.06$ & $0.34 \pm 0.08$ \\
4 & $0.34 \pm 0.07$ & $0.35 \pm 0.04$ & $0.34 \pm 0.06$ \\
\hline
\end{tabular}

Table 4. Chemical composition of commercial gelatin products as control

\begin{tabular}{lccc}
\hline \multirow{2}{*}{$\begin{array}{c}\text { Chemical } \\
\text { composition }\end{array}$} & \multicolumn{3}{c}{ Commercial gelatin product } \\
\cline { 2 - 4 } & $\begin{array}{c}\text { Pure } \\
\text { (Merck) }\end{array}$ & $\begin{array}{l}\text { Food } \\
\text { grade }\end{array}$ & $\begin{array}{c}\text { Pharmacy } \\
\text { standar }\end{array}$ \\
\hline $\begin{array}{l}\text { Gel strength } \\
\text { (g Bloom) }\end{array}$ & 75.29 & 68.17 & 72.27 \\
$\begin{array}{l}\text { Protein (\%) } \\
\text { Fat (\%) }\end{array}$ & 89.74 & 83.36 & 86.99 \\
$\begin{array}{l}\text { Water activity } \\
\text { (aw) }\end{array}$ & 0.61 & 0.67 & 0.52 \\
\hline
\end{tabular}

microbial growth. Sudarmadji et al. (2007) illustrated that $a_{w}$ value usually increased when a food product absorbed air from the environment as a result of the storage time process. Food products were located in the open air and the water level would reach equilibrium with the ambient humidity.

\section{Heavy Metals Content ( $\mathrm{Pb}, \mathrm{Cu}$, and $\mathrm{Zn})$}

One of the food safety requirements on the product gelatin was that heavy metals content must not exceed the allowed limit. Comparison of heavy metals content $(\mathrm{Pb}, \mathrm{Cu}$ and $\mathrm{Zn})$ in the goat skin gelatin, commercial gelatin (control), and Indonesian National Standards (INS) was presented in Figure 2.

The values of $\mathrm{Pb}$ metal in the goat skin gelatin and commercial vary (Figure $2 \mathrm{a}$ ). The amount of $\mathrm{Pb}$ metal found in the treatment of $\mathrm{T} 2 \mathrm{C} 3, \mathrm{~T} 2 \mathrm{C} 9, \mathrm{~T} 4 \mathrm{C} 3$, and $\mathrm{T} 4 \mathrm{C} 9$ was higher than other treatments and control, but still lower than the requirements of INS (50 ppm) (INS, 2005). Figure $2 \mathrm{~b}$ showed that $\mathrm{Cu}$ metal were higher in the treatment of T2C3, T2C6, T4C3 and T4C6 than others, but lower than the commercial, especially food grade gelatin (Fg) and than INS standard (30 ppm) (INS, 2005), while Figure $2 \mathrm{c}$ showed that goat skin gelatin and commercial contained $\mathrm{Zn}$ metal with different values, but lower than standard INS (100 ppm) (INS, 2005). Particularly in the commercial gelatin (food grade), the $\mathrm{Zn}$ metal was the highest.

Heavy metal elements contained by the goat skin gelatin were likely to come from: (1) feed and drinking water consumed by the goats and stored in the skin tissue, (2) water from the skin processing (soaking, unhairing, washing and neutralization), and (3) contamination of equipment in the production process. 


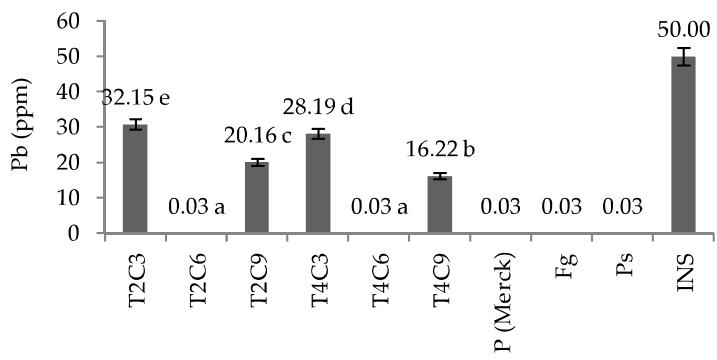

(a) Gelatin products

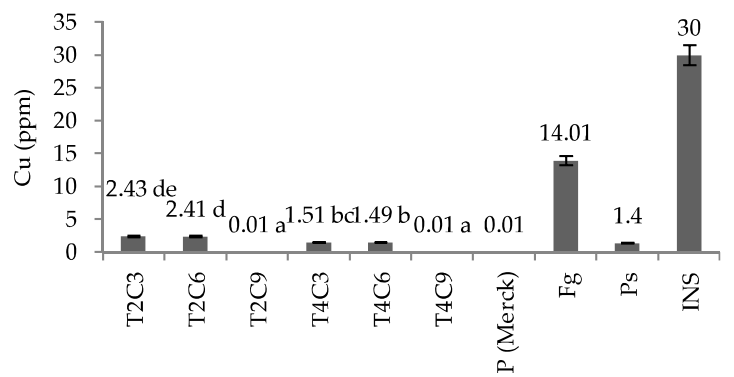

(b) Gelatin products

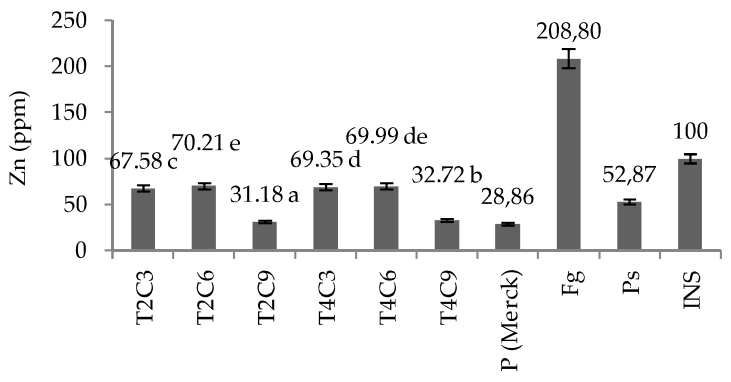

(c) Gelatin products

Figure 2. Comparison of heavy metals content of goat skin gelatin with commercial and INS; (a) $\mathrm{Pb}$; (b) $\mathrm{Cu}$; (c) $\mathrm{Zn}$; T2= curing time of 2 days; $\mathrm{T} 4=$ curing time of 4 days; $\mathrm{C} 3=$ concentration of $3 \% ; \mathrm{C} 6=$ concentration of $6 \% ; \mathrm{C} 9=$ concentration of $9 \% ; \mathrm{P}=$ pure by merck; $\mathrm{Fg}=$ food grade; Ps= pharmacy standart; INS= Indonesian National Standards. Means with different superscript differ significantly $(\mathrm{P}<0.05)$.

\section{Organoleptic Characteristic}

Organoleptic properties were important to consider because it related to consumer considerations in choosing a product (Suryati et al., 2006). Organoleptic refers to any sensory properties of a product, involving taste, colour, odour and feel. Organoleptic testing involves inspection through visual examination, feeling and smelling of products. According to Soekarto (2008), the organoleptic tests had high relevance to the quality of the product because it deals directly with consumer tastes. The comparison of organoleptic characteristics of goat skin gelatin and commercial was presented in Figure 3.

Figure 3 showed goat skin gelatin produced by alkali processes with $\mathrm{Ca}(\mathrm{OH})_{2}$ had a color similar to the commercial gelatin, a yellowish color as standard (INS, 2005). In addition to color, goat skin gelatin was more

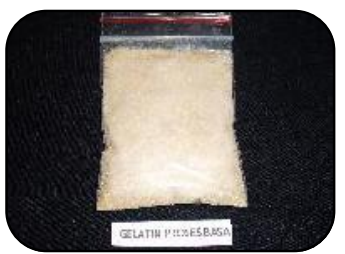

a

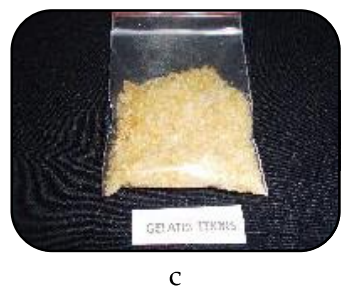

c

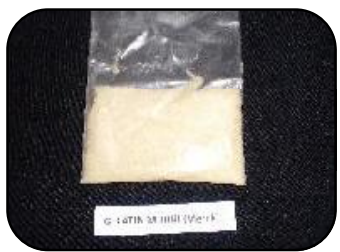

$\mathrm{b}$

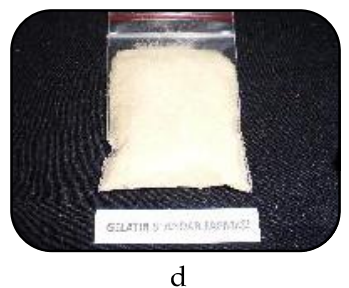

Figure 3. Physical appearance of the gelatin; (a) goat skin gelatin produced by $(\mathrm{Ca}(\mathrm{OH}) 2 ;(\mathrm{b})$ pure $(\mathrm{P})$ by Merck; (c) food grade $(\mathrm{Fg})$, and $(\mathrm{d})$ pharmacy standart $(\mathrm{Ps})$.

smooth and uniform than the food grade gelatin (Fg). According to Tyler \& Gregory (2005), the color differences on food products can be caused by the effect of temperature and $\mathrm{pH}$ in the production process.

\section{CONCLUSION}

The gelatin of goat skin produced using weak base $(\mathrm{CaOH})_{2}$ had similar gel strength, protein content, fat content, $a_{w}$ value, and color to the commercial gelatin. Optimum production results have been obtained from a combination of curing time of 4 days with a concentration of $9 \%(\mathrm{v} / \mathrm{v})$.

\section{ACKNOWLEDGEMENT}

Thanks to the Directorate-General of Higher Education, Ministry of National Education of Indonesia for the financial support through the research grants program for $\mathrm{PhD}$ students.

\section{REFERENCES}

AOAC. 2005. Official Methods of Analysis of AOAC International. $18^{\text {th }}$ ed. Assoc. Off. Anal. Chem., Arlington.

Arnesen, J. A. \& A. Gildberg. 2002. Preparation and characterization of gelatine from the skin of harp seal (Phoca groendlandica). Bioresource Technology. 82: 191-194.

Astawan, M. \& T. Aviana. 2003. The influence of type solution and drying methods on the physical properties, chemical and functional gelatin of skin from sword fish. J. Tech. \& Food Indust. 14: 7-13.

Bhat, R. \& A. A. Karim. 2009. Ultraviolet irradiation improves gel strength of fish gelatin. Food Chem. 113: 1160-1164 doi:10.1016/j.foodchem.2008.08.039.

Chiou, B., R. J. Avena-Bustillos, P. J. Bechtel, H. Jafri, R. Narayan, S. H. Imam, G. M. Glenn, \& W. J. Orts. 2008. Cold water fish gelatin films: Effects of cross-linking on thermal, mechanical, barrier, and biodegradation properties. European Polymer Journal 44: 3748-3753. doi:10.1016/ j.eurpolymj.2008.08.011.

Duan, R., J. Zhang, X. Du, X. Yao, \& K. Konno. 2008. Proper- 
ties of collagen from skin, scale and bone of carp (Cyprinus carpio). Food Chem. 112: 702-706.

Gilsenan, R. M., P. M. Gilsenan, \& S. B. Ross-Murphy. 2000. Rheological characterisation of gelatins from mammalian and marine sources. Food Hydrocolloid 14: 191-195.

Giménez, B., M. C. Gómez-Guillén, \& P. Montero. 2005. The role of salt washing of fish skins in chemical and rheological properties of gelatin extracted. Food Hydrocolloids. 19: 951-957.

Gómez-Estaca, J., L. Bravo, M. C. Gómez-Guillén, A. Alemán, \& P. Montero. 2008. Antioxidant properties of tuna-skin and bovine-hide gelatin films induced by the addition of oregano and rosemary extracts. Food Chem. 112: 18-25.

Gómez-Guillén., M. C., J. Turnay, M. D. Fernández-Dı' az, N. Ulmo, M. A. Lizarbe \& P. Montero. 2002. Structural and physical properties of gelatin extracted from different marine species: A comparative study. Food Hydrocolloids 16: 25-34.

Grobben, A. H., P. J. Steele, R. A. Somerville, \& D. M. Taylor. 2004. Inactivation of the bovine-spongiform-encephalopathy (BSE) agent by the acid and alkali processes used in the manufacture of bone gelatine. Biotech and App. Biochem. 39: 329-338.

Gudmundsson, M. 2002. Rheological properties of fish gelatin. J. Food Sci. 67: 2172-2175.

Hambidge, K. M. \& N. F. Krebs. 2007. Zinc deficiency: a special challenge. J. Nut.: 137 (Abstr.).

Hidaka, S. \& S. Y. Liu. 2002. Effect of gelatins on calcium phosphate precipitation: a possible application for distinguishing bovine bone gelatin from porcine skin gelatin. J. Food Comp. Analy. 16: 477-483.

INS. 2005. Indonesian National Standards. Number 06-37351995 about gelatin products. National Standardization Agency. Ministry of Industry and Trade of the Republic of Indonesia, Jakarta.

Jamilah, B \& K. G. Harvinder. 2002. Properties of gelatins from skins of fish black tilapia (Oreochromis mosambicus) and red tilapia (Oreochromis nilotica). Food Chem. 77: 81-84.

Jongjareonrak, A., S. Benjakul, W. Visessanguan, \& M. Tanaka. 2008. Antioxidative activity and properties of fish skin gelatin films incorporated with BHT and $\alpha$-tocopherol. Food Hydro. 22: 449-458.

Karim, A. A. \& R. Bhat. 2008. Gelatin alternatives for the food industry: recent developments, challenges and prospects. Trends in Food Sci. \& Tech. 19: 644-656. doi:10.1016/ j.tifs.2008.08.001 (In Press).

Kasankala, L. M., Y. Xue, Y. Weilong, S. D. Hong, \& Q. He. 2007. Optimization of gelatine extraction from grass carp (Catenopharyngodon idella) fish skin by response surface methodology. Bioresource Tech. 98: 3338-3343.

Kittiphattanabawon, P., S. Benjakul, W. Visessanguan, T. Nagai \& M. Tanaka. 2005. Characterisation of acid-soluble collagen from skin and bone of bigeye snapper (Priacanthus tayenus). Food Chem. 89: 363-372.
Kolodziejska, I., K. Kaczorowski, B. Piotrowska, \& M. Sadowska. 2003. Modification of the properties of gelatin from skins of Baltic cod (Gadus morhua) with transglutaminase. Food Chem. 86: 203-209.

Liu, H. Y., J. Han \& S. D. Guo. 2008. Characteristics of the gelatin extracted from channel catfish (Ictalurus punctatus) head bones. Food Sci. and Tech. 43: 313-317.

Muyonga, J. H., C. G. B. Cole \& K. G. Duodu. 2004. Extraction and physico-chemical characterization of Nile perch (Lates niloticus) skin and bone gelatin. Food Hydrocolloids. 18: 581-592.

Muyonga, J. H., C. G. B. Cole \& K. G. Duodu. 2003. Fourier transform infrared (FTIR) spectroscopic study of acid soluble collagen and gelatin from skins and bones of young and adult Nile perch (Lates niloticus). Food Chem. 86: 325332.

Ockerman, H. W. \& C. L. Hansen. 2000. Animal by Product Processing and Utilization. CRC Press, USA.

Soekarto, S.T. 2008. Organoleptic Assessment for the Food Industry. Bogor Institute of Agriculture, Bogor.

Songchotikunpan, P., J. Tattiyakul, \& P. Supaphol. 2007. Extraction and electrospinning of gelatin from fish skin. Internl. J. Biol. Macromolec. 42: 247-255.

Sudarmadji, S., B. Haryono, \& Suhardi. 2007. Analysis of Food and Agriculture. Issue $2^{\text {nd }}$. Cooperation Liberty of Yogyakarta with the Inter-University Centre for Food and Nutrition, Gadjah Mada University, Yogyakarta.

Suryati, T., M. Astawan, \& T. Wresdiyati. 2006. Characteristics organic of meat sheep given a low voltage electrical stimulation and injection of calcium chloride. Med.Pet. 29: 1-6.

Tyler, J. H. \& R. D. Gregory. 2005. An expeditions, high yield construction of the food aroma compound 6-acetyl-1,2,3,4tetrahydropyridine and 2-4 acetyl -1pyrrolyne. Journ. org. chem. 70: 10872-10874.

Wang, L., M. A. E. Auty, A. Rau, J. F. Kerry, \& J. P. Kerry. 2008a. Effect of $\mathrm{pH}$ and addition of corn oil on the properties of gelatin based biopolymer film. J. Food Eng. 90: 11-19.

Wang, L., B. Yang, R. Wang, \& X. Du. 2008b. Extraction of pepsin-soluble collagen from grass carp (Ctenopharyngodon idella) skin using an artificial neural network. Food Chem. 111: 683-686.

Yudhabuntara, D. 2008. Control of Microorganisms in Food. http://milkordie.blogspot.com/2008/05/ control - microorganisms -in-food.html [December 23, 2009].

Zeugolis, D. I., S. T. Khew, E. S. Y. Yew, A. K. Ekaputra, Y. W. Tong, L. L.Yung, D. W. Hutmacher, C. Sheppard, \& Michael. 2008. Electro-spinning of pure collagen nano-fibres - Just an expensive way to make gelatin ?. Biomaterials. 15: 2293-2305.

Zhang, Y., W. Liu, G. Li, B. Shi, Y. Miao, \& X. Wu. 2007. Isolation and partial characterization of pepsin-soluble collagen from the skin of grass carp (Ctenopharyngodon idella). Food Chem. 103: 906-912. 